\title{
Conviver com a Sindrome de Down em Escola Inclusiva
}

\author{
Maria Madalena Moraes Sant ${ }^{\prime}$ Anna ${ }^{1}$
}

\begin{abstract}
PIMENTEL, Susana Couto. Conviver com a Sindrome de Down em escola inclusiva: mediação
\end{abstract} pedagógica e formação de conceitos. Petrópolis: Vozes; Coleção Educação Inclusiva, Petrópolis, RJ, 2012. 190 p.

O assunto apresentado nesta obra é o resultado da pesquisa desenvolvida por Susana Couto Pimentel em seu doutorado no Programa de Pós-Graduação da Universidade Federal da Bahia, fazendo uso de uma análise microgenética do processo de formação de conceitos por estudantes com Síndrome de Down na escola regular. Tem como proposta discutir a formação do pensamento conceitual a partir da atuação do professor como mediador pedagógico, demostrando como estes estudantes com síndrome de Down se apropriam, no contexto escolar, dos conceitos propostos e sistematizados pela escola no processo de educação inclusiva.

O estudo é descrito a partir de uma breve introdução e apresenta ao leitor as etapas iniciais da pesquisa. Além de apontar os autores que sustentaram a sua fundamentação teórica, descreve o processo de análise microgenética, realizado a partir da interação com as crianças com Síndrome de Down através da observação participante, entrevistas e aplicação de instrumento de conceituação, além da análise de documentos escolares e das produçóes das crianças. A autora relata que a análise dos dados foi realizada a partir da triangulação dos dados obtidos por meio dos procedimentos acima descritos.

No primeiro capitulo, a autora discorre sobre a presença de crianças com Síndrome de Down na escola, salientando que os primeiros momentos de aprendizagem se iniciam a partir das intervençóes de estimulação precoce e devem ser acessíveis a toda a comunidade, sem focar somente o aspecto clínico, mas buscar a inserção destas crianças em um processo inclusivo desde a educação infantil, incluindo o investimento nas relaçôes familiares. Relata também que, se esta criança tiver esta etapa garantida, com certeza alcançará o desenvolvimento da linguagem, extremamente relacionado com as interaçóes que estabelece. As açóes interpretadas e significadas pelo outro possibilitam o início da construção de sua linguagem.

Apresenta também um breve relato histórico sobre a escolarização destas crianças. Para que haja um avanço neste processo, deve-se garantir a formação de todos os profissionais da escola, a adaptação curricular e o apoio aos pais.

Dentre várias discussóes relevantes, a autora apresenta de forma clara e objetiva os dois enfoques de educação nos quais os currículos escolares destas crianças estão centrados: o tradicional e o cultural-integrador. Neste último, é apontado como dever da escola dar respostas às demandas dos estudantes. Além disso, marca que as adaptaçóes nos elementos básicos do currículo envolvem ajustes quanto à forma de avaliação, à metodologia e ao conteúdo. Para estas

${ }^{1}$ Doutoranda do Programa de Pós-Graduação em Educação - Linha Educação Especial da UNESP - Marilia - SP 
adaptaçóes serem reais, são necessárias modificaçóes para responder às necessidades específicas de aprendizagem destes estudantes.

No segundo capítulo a autora aborda, através de uma apresentação teórica detalhada, os processos psicológicos que envolvem a formação de conceitos, a atenção, a percepção e a memória, a generalização, o pensamento e a linguagem. Seu relato é permeado pela descrição de como se processa a formação do pensamento conceitual, sustentada a partir da perspectiva histórico-cultural, analisando a influência dos processos psíquicos neste processo e considerando também que todo o psiquismo humano é estruturado através da linguagem.

Através dos estudos de Vygostsky (1996) são apresentados os dois tipos de conceitos, os cotidianos e os científicos. A autora aponta que a simples transmissão de um conceito pelo professor não garante a aprendizagem para a criança. É reforçada a importância do professor "mediador", que dá condiçóes à criança de encontrar estratégias que possibilitem a solução de problemas para favorecer a elaboração de conceitos e as mediaçóes pedagógicas acontecerem dentro da zona de desenvolvimento proximal (ZDP).

Ainda neste capítulo, há uma discussão a propósito das dificuldades que as crianças com Síndrome de Down podem apresentar na aquisição de linguagem, principalmente devido às características relacionadas à hipotonia dos órgãos fonoarticulatórios, juntamente com o atraso no desenvolvimento cognitivo, ressaltando que os interlocutores com quem a criança com Síndrome de Down interage devem estar atentos às formas diversas com que esta criança pode manifestar sua linguagem: oral, gestual, gráfica, entre outras.

No terceiro capítulo são apresentados conceitos sobre mediação como elemento de (trans)formação humana. A autora ressalta que, na relação ensino/aprendizagem, mediar representa dar níveis de colaboração planejados e que se adequam as necessidades dos educandos. A mediação em uma escola inclusiva significa o reconhecimento das peculiaridades, características, potencialidades, oferecendo respostas adequadas às necessidades, garantindo a interação entre "professor-aprendente" e "entre aprendentes". Pontua que, com a criança portadora de Síndrome de Down, esta mediação, inserida em um contexto escolar que proporciona desafios, poderá facilitar o processo de formação de conceitos, principalmente devido ao atraso cognitivo esperado nesta população.

No quarto e quinto capítulos são apresentados a análise dos resultados, dos momentos de mediação, intervenção e observação com a aluna com síndrome de Down tanto da professora quanto da pesquisadora, em uma sala de aula de $1^{\text {a }}$ série do ensino fundamental nos momentos de aquisição da linguagem escrita e outra na $2^{\text {a }}$ série, em relação aos conceitos de ciência.

A autora aponta as limitaçóes do professor em mediar o processo de ensino de língua escrita, mesmo que este apresente o desejo de aperfeiçoar a sua prática, marcando o conceito de ação colaborativa nos momentos de troca entre pesquisador e professor, a importância destes momentos e a falta de preparo de todos os atores da escola como pontos de interferência para um melhor aproveitamento da mediação pedagógica por parte da aluna.

Sobre os conceitos de mediação pedagógica, aponta algumas reflexôes sobre as dificuldades e as possibilidades na operacionalização na escola pesquisada. A vivência desta aluna neste grupo é um pouco dificultada também, pois ela náo consegue estruturar o que a 
autora denomina de "cooperação dos colegas", tendo sempre a mesma amiga como par para atividades em grupo. Nos momentos difíceis, ela começa uma atividade e muitas vezes não a finaliza, sai da sala e fica fora por tempo prolongado. Nesta relação estabelecida com uma colega, percebeu-se que a regra na execução da atividade é de fazer "com" e não "por" ela, sendo esta a vivência desejada para a prática cotidiana no processo de inclusão de alunos com necessidades educacionais especiais.

No relato da estudante na $2^{\text {a }}$ série fundamental sobre o ensino de ciências, a pesquisadora faz uso do instrumento de conceituação adaptado do Teste de Audibilização, parte III, de Clarissa Goldbert, que aponta as potencialidades da estudante com Síndrome de Down, concluindo que a utilização de recursos visuais no ensino pode favorecer o processamento de conceitos trabalhados.

Considera-se que esta obra aponta caminhos para a importância da mediação pedagógica na efetivação do processo de formação do pensamento conceitual, que é caracterizado como a possibilidade de construir uma nova ideia científica sem abandonar a anterior que lhe serve de fundamento, e a eficácia da análise microgenética como método de investigação em educação.

Abrem-se assim reflexôes sobre a necessidade de garantir mediaçôes efetivas através de um melhor investimento no preparo de professor, do grupo e das famílias envolvidas no processo de aprender na escola, sobre a necessidade de diminuir o número de alunos em sala, parcerias de colegas mais efetivas, enfim, a formação de todos os atores para que, verdadeiramente, a inclusão de pessoas com necessidades educacionais especiais possa ser efetivada. 